\title{
A112 後向きステップ下流の温度場の可視化・伝熱特性
}

\section{Thermo Image and Heat Transfer behind Backward-Facing Step}

\author{
○宮藤 義孝(琉球大院)，屋我 実(琉球大工) \\ 照屋 功, 瀬名波 出, 親川 兼勇 \\ Yoshitaka MIYAFUJI', Minoru YAGA' \\ Isao TERUYA ${ }^{1}$, Izuru SENAHA ${ }^{1}$, KenYu OYAKAWA ${ }^{1}$
}

1 University of the Ryukyus, Senbaru-1, Nishihara Okinawa, 903-0213

\begin{abstract}
Thermo images and heat transfer characteristics downstream of a backward-facing step were measured varying separation distances between pairs vortex generators which were set upstream of an entrance of step in order to control the heat transfer. The pair of vortex generators is made of two rectangular blades widening downstream. Addition of the longitudinal vortex which is produced by the vortex generators to the main shear layer flow separated from step entrance caused the reattachment point of main flow to move upstream, suppressed the fluctuation of reattachment flow, and the heat transfer consequently was improved in the recirculation region.
\end{abstract}

\section{Keywards: Reattachment flow, Thermo images, Heat transfer characteristics, Longitudinal vortex}

\section{1. 緒言}

はく離, 再付着現象を伴う基本的な流れの1つである後 向きステップ流れは，工学的な装膡として多く見られこ れまで数多くの研究がなされてきた".本研究では, ステッ プ上流の流れに維渦を付加することにより，はく離せん断 層により大きな誘引を引き起こさせることで, 再付着位置 を上流側へ移動させることを考えた、ステップ上流に流れ に対して傾けた複数の翼对(ボルテックス・ジェネレータ, 以下 V.G.)を設置し, 維渦を発生させる. 赤外線映像装置 により,ステップ下流の再付着点近傍の全面の瞬間的な温 度分布を測定し，V.G.設置による時間的・空間的な熱移動 現象を観察した. 温度分布の可視化との比較のために，熱 電対を用いてステップ下流の局所熱伝達率を測定した. 可 視化された温度場と局所熱伝達率を対比することにより妘 熱特性を解明する。なお，V.G.下流の基本的な温度場を知 る目的から, 平行平板流路内にV.G. を設置し, 近傍の瞬間 的な温度分布も測定した。

2. 実験裝置および実験方法

実験装置は, 流路高さ $\mathrm{H} 0=60 \mathrm{~mm}$ ，スパン幅 $300 \mathrm{~mm}$ の断 面をもつ, 片面断熱流路である.ノズルを介して作動流体 として空気が流入される. ステップ側の伝熱板は, ベーク ライト板に厚さ $30 \mu \mathrm{m}$ のステンレス箔を接着し, 通電加 熱することにより，熱流束を一定にした。ステップ高さ $\mathrm{H}=40 \mathrm{~mm}$ で一定とし，ステップ上端部にV.G.を設置した. なお，拡大比 $\mathrm{ER}=(\mathrm{H} 0+\mathrm{H}) / \mathrm{H}_{0}=1.67$ である、装置の概略およ び観測空等を Fig.1に示す. 赤外線映像装置は赤外線セン サに水平 160 と垂直 120 素子のインジウム・アンチモン (InSb)が搭載され，掃引時間は約 $1 / 100$ 秒で, 2 次元温度分 布を熱画素として取り込み，映し出すものである．温度分

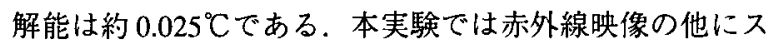
テンレス箔轺面に流れ方向にハンダ付けされた $70 \mu \mathrm{m} の$ 銅 -コンスタンタン熱電対 53 本により壁面温度を測定し, 熱伝達率も求めた. スパン方向の局所分布はV.G.位置を移 動させて測定した. 実験に使用したV.G.の配置図と寸法を Fig. 2 に示す. V.G. 幅 $W=30.0 \mathrm{~mm}, 50.0 \mathrm{~mm}$ の2 種類につい て実験を行った。

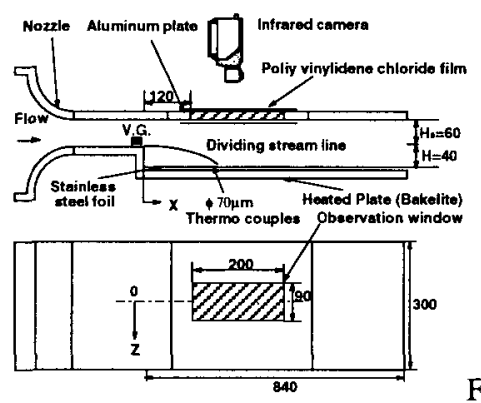

Fig.1 Experimental apparatus and Infrared camera

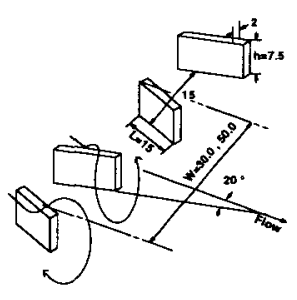

Fig.2 Arrangement of pairs of winglets as vortex generators

3. 実験結果および考察

3.1 赤外線映像による温度分布

V.G. 近傍および下流域の赤外線映像装置のデー夕を基 に描いた温度分布をFig.3に示す.各等温線図の間隔は 0.5 ゚で゙，横軸および縦 軸は流路高さ $\mathrm{H}_{0}$ で 無次元化してい

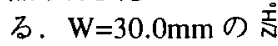
場合, V.G.の前縁 付近で大きな周期 的温度分布を示 す.V.G.による主 巻き込み渦の吹き 下ろしによって, 1 つのV.G.の背面は 局部的に冷えてい ることがわかる。 $\mathrm{X} / \mathrm{H}_{0}=0.5$ 付近から 縦渦と隣接の縦渦 の相互助長作用に より，周期的温度 分布は小刻みとな る. $\mathrm{W}=50.0 \mathrm{~mm} の$

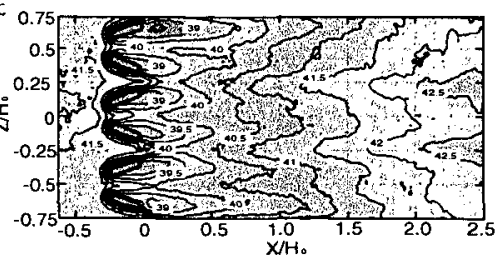

(a). $\mathrm{W}=30.0 \mathrm{~mm}$

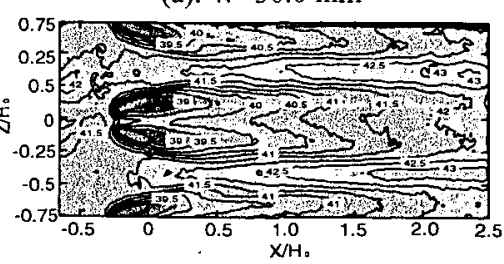

(b). $\mathrm{W}=50.0 \mathrm{~mm}$

Fig.3 Isotherm contours near vortex generators being set in a parallel plate duct 
場合, V.G.とV.G.の間では，間隔が広いため，温度の急 激な変化は見られない.しかし，1対のV.G.の背面では； $\mathrm{W}=30.0 \mathrm{~mm}$ の場合と同様に, 局部的に冷え, $40^{\circ} \mathrm{C}$ 等温度 線に注目すると，絴渦による伝熱促進の効果が $\mathrm{W}=30.0 \mathrm{~mm}$ に比へ，下流域にまで及んでいることがわか る、ただし，V.G.ごとに独立した温度分布であり，維渦 と絴渦による相互助長作用は弱いことがわかる。

流速 U $=15.0 \mathrm{~m} / \mathrm{s}\left(\operatorname{ReH}_{\mathrm{H}}=37000\right)$ でステップ下流の再付着点 近傍の温度分布の測定を行った。V.G.がない場合(以下 smooth), W=30.0mm, $50.0 \mathrm{~mm}$ における等温度線の分布を

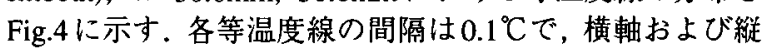
軸はステップ高さHで無次元化した. smoothの場合, 低 温度領域が $\mathrm{X} / \mathrm{H}=4.0 \sim 6.0$ の範囲で存在し, $\mathrm{Z} / \mathrm{H}= \pm 0.5 \sim$ \pm 1.125 にあり，40.1 ${ }^{\circ} \mathrm{C}$ 示している。本実験で, 再付着 領域は時間的·空間的に変動し, 低温度領域の合体·分離 を繰り返し，常に流れ方向およびスパン方向に摇動して いることが確認された. $W=30.0 \mathrm{~mm} の$ 場合, 低温度領域が $\mathrm{X} / \mathrm{H}=3.0 \sim 5.0, \mathrm{Z} / \mathrm{H}=-0.5 \sim-1.125$ の範囲で存在し, $\mathrm{X} / \mathrm{H}=4.0$ で $38.9^{\circ} \mathrm{C}$ 示していて，V.G.によって形成された縦渦と はく離せん断層内の3次元的な渦が相互作用し, 偏って伝 熱板上に再付着していると考えられる. 再付着領域の時 間的・空間的な変動は, smooth に比心低温度領域の僅か な拡大・縮小をともなうものの, 抑えられていることが確 認された. $W=50.0 \mathrm{~mm}$ の場合, 低温度領域が $\mathrm{X} / \mathrm{H}=3.0$ 一 $5.0, \mathrm{X} / \mathrm{H}=-0.5 \sim 0.5$ および $\mathrm{Z} / \mathrm{H}= \pm 1.0 \sim \pm 1.125$ の範囲で 3 個存在し, 真中の低温度領域では, $\mathrm{X} / \mathrm{H}=4.0 に 38.5^{\circ} \mathrm{C} の$ 温度域が存在す る. 3 個の低温度 領域はV.G.の配 列に依っており, $\mathrm{W}=30.0 \mathrm{~mm}$ の時 と同様に smooth に比べ，上流側に 移動して扔り，か つ再付着領域の一 時間的・空間的な二 変動が抑えられ二志 ていることが確二 認された.はく離一 せん断層内のラ ンダムで 3次元的 かつ大規模な渦 が, 縦渦の付加に よって, 誘引流量 加増加し, 主流は より大きく湾曲 し, 上流側に再付 着する。その際， 絴渦による誘引 流量が,スパン力 向の流れ場をあ

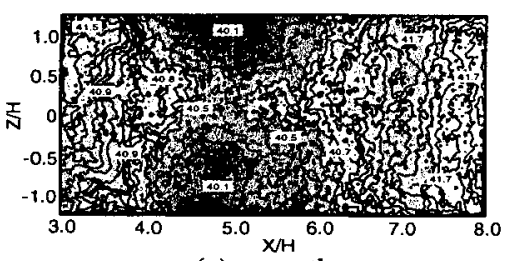

(a). smooth

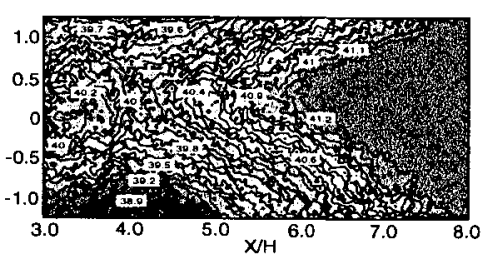

(b). $\mathrm{W}=30.0 \mathrm{~mm}$

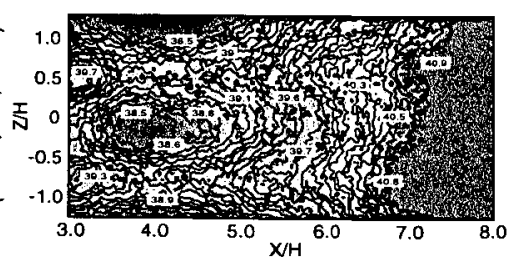

(c). $\mathrm{W}=50.0 \mathrm{~mm}$

Fig.4 Isotherm contours near reattachment region
る程度決め, 規則正しい小規模な渦に変えることにより， はく離せん断層はスパン方向にて局所的に再付着すると考 えられる。

\section{2 局所熱伝達率分布}

流れ方向, 流路中央の局所熱伝達率分布を Fig.5に示す. V.G.のある場合が, smoothに比べ，最大熱伝達率は増加 し，その位置はX/H=6よりかなり上流側に移動している. Fig.4の赤外線画像と対比させると, 多少のずれはあるも
のの，傾向は，ほとんど一致している．スパン方向の代表 的な局所熱伝率を Fig.6に示す. 図中に各プロットの平均 值を点線で示してある. $\mathrm{X} / \mathrm{H}=4$ において, $\mathrm{W}=30.0 \mathrm{~mm}$ では, 右下がりの分布となり，W=50.0mmでは，V.G.の影響を うかがわせる2つの下に膨らみを持った分布がみられる。 $\mathrm{X} / \mathrm{H}=6$ では， $\mathrm{X} / \mathrm{H}=4$ と相似な分布をとり, $\mathrm{W}=50.0 \mathrm{~mm}$ では, 2つの膨らみを持った分布が一段とはっきりしてくる．X/ $\mathrm{H}=8$ では, $\mathrm{W}=30.0 \mathrm{~mm}$ は $\mathrm{X} / \mathrm{H}=4$ と相似な分布をとるもの の, W=50.0 mmではスパン方向に均一な分布に戻りつつ ある.各スパンの局所熱伝達率を平均し, その值の流れ方 向の変化を Fig.7 に示す．W=30.0mm においては，X/H=4 の位置で, $W=50.0 \mathrm{~mm}$ 。 では, X/H=5の位置でき 最大值をとる. $\mathrm{X} / \mathrm{H}=7$ 的 以降で $\mathrm{W}=30.0 \mathrm{~mm}$ の方爻 が平均の熱伝達率が高 いことから，下流域ま で伝熱促進を図るには,Fig.5 Streamwise variation of local V.G. 幅が狭い方が有効 であることがわかる.
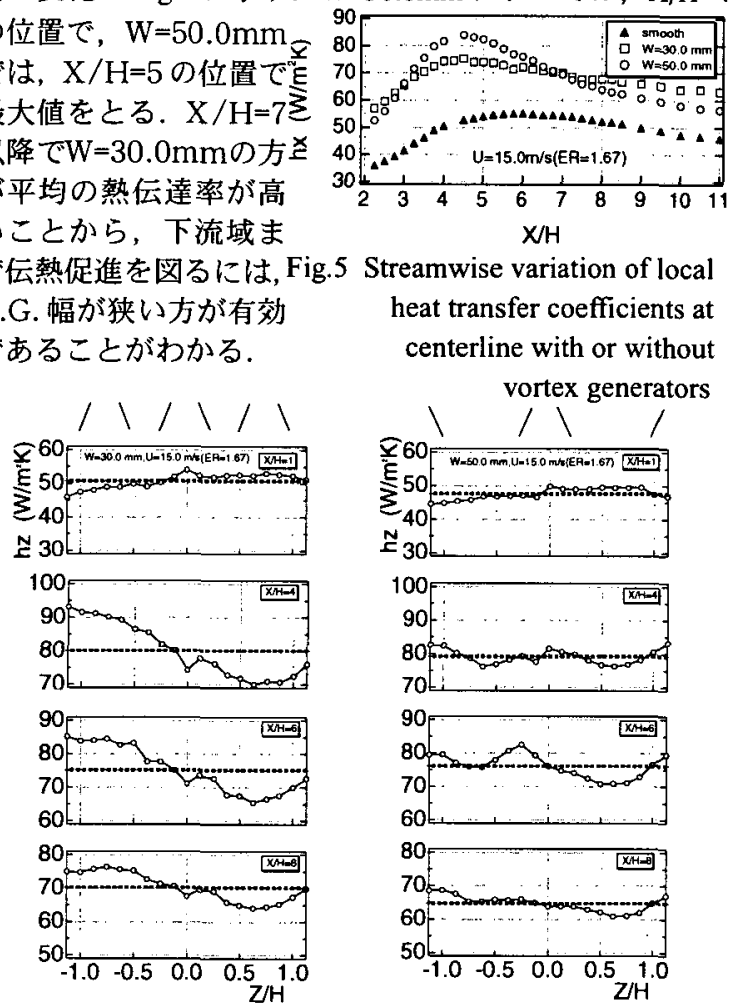
heat transfer coefficients at centerline with or without
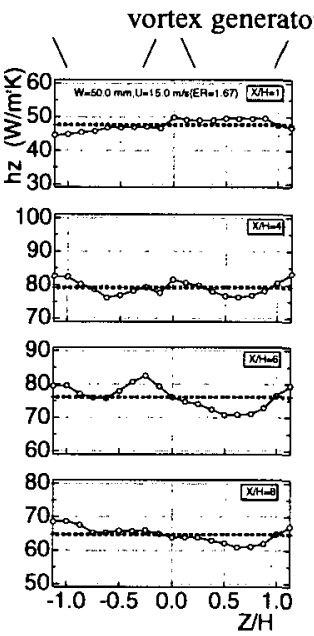

Fig.6 Distribution of spanwise local heat transter coettıcients 4. 結言

1) V.G. 幅 $W=30.0 \mathrm{~mm}$ では，再付着点が上流 側に大きく移動し，最 大熱伝達率および局所䄱 値が增大した。温度分 布は，V.G.によって生 成される縦渦およびは く離せん断層内の渦が 複雑に干渉しあい, 低 温度領域が 中央ではなく偏った分布をとる with W 2) V.G. 幅W=50.0 mmでも，熱伝達率が増加し，V.G.に よる縦渦の影響がスパン方向に明らかに顕れ，温度分布， 局所熱伝達率分布の変化が明確になる。

3) 再付着領域は, V.G.を使用することにより，上流側へ 移動し, 摇動を隇少させ局所的な低温度領域を形成する. $\mathrm{W}=30.0 \mathrm{~mm}$ は再付着の領域, $\mathrm{W}=50.0 \mathrm{~mm}$ は再付着下流にお ける熱伝達增大に大きく寄与する。

\section{参考文献}

1）親川・他 2 名, 噴流による後向きステップ下流の再循 環領域の熱伝達特性の制御に関する研究, 日本機械学会 論文集, B, Vol.60，No.569(1994)，pp.248-254 